\title{
HUBUNGAN ANTARA PENGUASAAN TATA BAHASA JERMAN DENGAN KETERAMPILAN MENULIS PARAGRAF DESKRIPTIF SISWA KELAS XI SMA NEGERI 1 PALOPO
}

\author{
Desi Sugiarti ${ }^{1}$ dan Muddin ${ }^{2}$ \\ Fakultas Bahasa dan Sastra, Universitas Negeri Makassar \\ E-mail ${ }^{1}$ :desitandilino@gmail.com
}

\begin{abstract}
ABSTRAK
Penelitian ini bertujuan untuk mengetahui hubungan antara penguasaan tata bahasa Jerman dengan keterampilan menulis paragraf deskriptif kelas XI SMA Negeri 1 Palopo. Pengumpulan data pada penelitian ini diperoleh dengan tes tertulis dan dianalisis melalui korelasi Product Moment. Populasi dalam penelitian ini adalah siswa kelas XI IPA yang berjumlah 350 orang. Populasi penelitian dipilih melalui teknik Random Sampling. Berdasarkan hasil analisis data melalui korelasi Product Moment, diperoleh hasil $\mathrm{r}_{\text {hitung }}=(0,240)<\mathrm{r}_{\text {tabel }}=(0,334)$, hasil penelitian menunjukkan bahwa tidak ada hubungan yang signifikan antara penguasaan tata bahasa Jerman dengan keterampilan menulis paragraf deskriptif siswa kelas XI IPA 1 SMA Negeri 1 Palopo.
\end{abstract}

\section{Kata Kunci : Tata Bahasa, Paragraf Deskriptif, dan Bahasa Jerman}

\begin{abstract}
The aim of this study was to find the correlation between grammar domination and the ability to write the paragraph description of students of the eleventh grade at SMA Negeri 1 Palopo. The data were taken by the literal test and were analyzed with the correlation Product Moment. The population was the eleventh grade pupil, which consisted of 350 pupils. The population is selected by random sampling. The result was $r$ calculation $=0.240<\mathrm{rTable}=0.344$, there was no significant correlation between the grammar mastery with the paragraph description of the eleventh grade students at the SMA Negeri 1 Palopo.
\end{abstract}

\section{Keywords: Grammar, Descriptive Paragraph, and German Language}

\section{PENDAHULUAN}

Manusia sebagai makhluk sosial tidak dapat dipisahkan dari bahasa.Bahasa merupakan suatu alat komunikasi yang digunakan oleh manusia dalam kesehariannya untuk berinteraksi dengan sesama. Melalui penggunaan bahasa manusia dapat saling mengenal satu dengan yang lain, dapat saling bertukar pikiran, bahkan dengan adanya bahasa seseorang dapat memeroleh banyak informasi dari berbagai sumber sehingga memiliki wawasan yang luas. Agar memiliki wawasan yang luas diperlukan adanya penguasaan bahasa.Penguasaan bahasa yang dimaksud tidak hanya penguasaan bahasa 
daerah maupun bahasa nasional saja melainkan penguasaan bahasa asing sangat penting dimiliki pada era perkembangan teknologi saat ini.

Penguasaan bahasa asing pada era perkembangan teknologi saat ini tentunya sangat menunjang khususnya pada pemerolehan informasi. Oleh karena itu pentingnya penguasaan bahasa asing beberapa Sekolah Menengah Atas menjadikan bahasa Jerman sebagai salah satu mata pelajaran bahasa asing yang tentunya sangat membantu dalam pengetahuan bahasa Jerman dan pengetahuan tentang ragam budaya Jerman Mantasiah (2016), Nurmiati (2017).

Ada empat aspek yang terdapat dalam pembelajaran bahasa Jerman diantaranya : kemampuan menyimak (Hörverstehen), keterampilan berbicara (Sprechfertigkeit), keterampilan menulis (Schreibfertigkeit) dan kemampuan membaca (Leseverstehen), serta ditunjang oleh dua aspek kemampuan yaitu: tata bahasa (Strukturen) dan kosakata (Wortschatz) yang saling berkaitan dalam proses penguasaan bahasa Jerman. Oleh karena itu,penguasan keempat aspek serta dua penunjang tersebut dapat diperoleh dengan adanya latihan dan praktik yang dilakukan secara terus-menerus.

Pembelajaran bahasa asing khususnya bahasa Jerman aturan tertentu untuk menyusun sebuah kalimatdisebut tata bahasa (Strukturen). Tata bahasa merupakan aturan yang sangat penting untuk dikuasai dalam

\section{TATA BAHASA}

Tata bahasa merupakan suatu sistem atau aturan penyusunan beberapa kata menjadi sebuah kalimat yang dipelajari oleh para proses pembelajaran bahasa Jerman. Oleh karena itu, penguasaan tata bahasa yang memadai dapat menunjang proses pembelajaran bahasa asing.

Bersumber pada hasil wawancara yang dilakukan penulis dengan guru bidang studi bahasa Jerman di SMA Negeri 1 Palopo diperoleh informasi bahwa sebagian besar siswa masih mengalami kesulitan dalam mengungkapkan gagasan berupa tulisan yang sesuai dengan pola tata bahasa. Hal tersebut didukung oleh beberapa hasil penelitian sebelumnya seperti yang telah dilakukanoleh Mulyati (2015:112) menunjukkan bahwa pengaruh signifikan penguasaan gramatik terhadap keterampilan menulis bahasa Jeman sebesar 19,54\%. Selanjutnyapenelitian yang dilakukan oleh Niaryanti (2015:46) menunjukkan bahwa terdapat hubungan antara penguasaan gramatik dengan keterampilan menulis karangan sederhana bahasa Jerman yang ditunjukkan dengan koefisien korelasi sebesar 0,511 yang termasuk pada kategori sedang.

Berdasarkan uraian di atas, maka perlu dilakukan penelitian untuk mengetahui kontribusi penguasaan tata bahasa dengan keterampilan menulis paragraf deskriptif yang dilakukan di SMA Negeri 1 Palopo dengan judul : "Hubungan Antara Penguasaan Tata Bahasa Jerman dengan Keterampilan Menulis Paragraf Deskriptif Siswa Kelas XI SMA Negeri 1 Palopo"

pembelajar bahasa khususnya pada bahasa asing seperti pada bahasa Jerman. Penguasaan tata bahasa yang cukup akan sangat menunjang bagi para pembelajar bahasa untuk menuturkan bahasa asing lebih baik. 
Menurut Hartmund Kleineldam, Bausch, Lia Fitriani (2014) tata bahasa adalah suatu deskripsi tertulis yang terdiri atas aturan atau kaidah suatu bahasa dalam bentuk sebuah buku yang menjadi dasar untuk membuat kalimat Hal yang sama juga dikemukakan oleh Grötz dalam Lia Fitriani 2014 "Grammatik ist Regeln einer Sprache, nach denen in ihrer Sprachlichen Form verändert und zu Sätzen kombiniert werden”. Makna dari penyataan tersebut yaitu bahwatata bahasa merupakan sebuah aturan sebuah bahasa, dimana kata-kata diubah dalam bentuk tata bahasanya dan dikombinasikan dalam kalimat. Sri Mulyati (2015 : 34) mengemukakan bahwa tata bahasa merupakan suatu aturan tata bahasa yang dapat menyusun kata-kata menjadi sebuah kalimat yang efektif.

Berdasarkan pendapat tersebut dapat disimpulkan bahwa tata bahasa merupakan suatu aturan bahasa yang dapat membantu seseorang dalam merangkai kata-kata menjadi sebuah kalimat yang baik sesuai dengan kaidah.

\section{KEMAMPUAN MENULIS}

Menulis merupakan suatu keterampilan produktif yang bertujuan untuk menyampaikan makna dalam bentuk lambang tulisan. Kegiatan menulis tersebut diantaranya mengungkapkan ide, gagasan, pikiran, atau perasaan kepada pembaca. Kast dalam Pramita Destari 2013 mengemukakan bahwa das Schreiben wird das als Zielfertgkeit eingeübt, d.h es wird geschrieben, um keterampilan menulis paragraf deskriptif. Penguasaan tata bahasa Jerman yang dimaksud dalam penelitian ini ialah
Informationen zu geben und mit jemandem in Kontakt zu bleiben. Menulis merupakan suatu keterampilan yang dilatih berupa menuliskan sesuatu yang bertujuan memberikan informasi dan tetap berkaitan dengan seseorang. Maksud dari pendapat di atas yaitu menulis merupakan suatu keterampilan menuangkan gagasan lewat tulisan yang bertujuan untuk menginformasikan sesuatu kepada pembaca.

Dalman (2015:3) menjelaskan bahwa menulis merupakan sebuah proses kreatif menuangkan gagasan dalam bentuk bahasa tulis dalam tujuannya, misalnya memberitahu, meyakinkan, atau menghibur. Menurut Tarigan (2013:3) menulis merupakan suatu keterampilan berbahasa yang dipergunakan untuk berkomunikasi secara tidak langsung, tidak secara tatap muka dengan orang lain. Berdasarkan beberapa pendapat di atas dapat disimpulkan bahwa menulis merupakan suatu proses keterampilan yang bertujuan untuk memberikan informasi kepada pembaca.

\section{METODE PENELITIAN}

Penelitian ini menggunakan dua variabel yaitu penguasaan tata bahasa Jerman siswa sebagai variabel bebas (X) dan keterampilan menulis paragraf deskriptif sebagai variabel terikat (Y). Penelitian ini merupakan penelitian korelasi yang bertujuan mengetahui hubungan antara penguasaan tata bahasa Jerman dan keterampilan menulis paragraf deskriptif siswa kelas XI SMAN 1 Palopo.

Pada bagian sebelumnya telah dijelaskan bahwa penelitian ini terdiri atas dua variabel yaitu penguasaan tata bahasa Jerman dan kemampuan siswa dalam menggunakan struktur kalimat atau tata bahasa Jerman. Kemampuan tersebut meliputi: (1) kalimat 
präsens, (2) kata ganti orang (Personalpronomen), (3) pembentukan kata kerja (konjugasi kata kerja), (4) kata ganti kepunyaan (Possesivepronomen), dan (5) penulisan kata benda bahasa Jerman. Kemudian Keterampilan menulis yang dimaksud dalam penelitian ini adalah keterampilan siswa dalam menulis paragraf deskriptif berdasarkan tema yang diberikan.

Populasi dalam penelitian ini adalah siswa kelas XI IPA SMA Negeri 1 Palopo yang tediri atas 4 kelas. Sampel penelitian ini adalah siswa kelas XI IPA 1 SMAN 1 Palopo dengan menggunakan teknik random sampling (sampel acak) dengan jumlah sampel 35 siswa. Data yang diperoleh dari tes penguasaan tata bahasa Jerman dan keterampilan menulis paragraph deskriptif diuji dengan menggunakan rumus korelasi Product Moment.

\section{HASIL DAN PEMBAHASAN}

\section{Hasil Analisis Data Tes Penguasaan Tata Bahasa Jerman}

Tahapan ini merupakan paparan hasil analisis data mengenai nilai yang diperoleh siswa dalam tes penguasaan tata bahasa Jerman.Skor terendah yang diperoleh siswa pada tes penguasaan tata bahasa Jerman adalah 12 dan skor tertinggi yang diperoleh siswa adalah 36. Berdasarkan hasil analisis data dari keempat macam tes skor rata-rata yang diperoleh siswa pada tes pengunaan kata ganti orang (Personalpronomen) 8,91; kata ganti kepunyaan (Possessivepronomen) 5,57; konjugasi kata kerja 5,37; dan menyusun kata 3,6. Berdasarkan 35 sampel diperoleh data bahwa sebanyak 5 siswa berada pada kelas interval 12-16 dengan persentase sebesar
14,3\%, 7 siswa pada kelas interval 17-20 dengan persentase sebesar 20\%, 6 siswa pada kelas interval 21-24 dengan persentase sebesar 17,14\%, 9 siswa pada kelas interval 25-28 dengan persentase sebesar 25,71\%, 7 siswa pada kelas interval 29-32 dengan persentase sebesar $20 \%$, dan 1 siswa pada kelas interval 33-36 dengan persentase sebesar $2,86 \%$.

\section{Hasil Analisis Tes Keterampilan Menulis Paragraf Deskriptif}

Tahapan ini merupakan paparan hasil analisis data mengenai nilai yang diperoleh siswa dalam tes keterampilan menulis paragraf deskriptif. Data yang diperoleh untuk variabel keterampilan menulis paragraf deskriptif cukup sederhana yaitu skor terendah yang dicapai oleh siswa adalah 5 dan skor tertinggi yang dicapai oleh siswa adalah 10. Bersumber pada data tersebut menunjukkan bahwa dari 35 sampel diperoleh data bahwa sebanyak 2 siswa memeroleh skor 5 dengan persentase sebesar 5,71\%, 18 siswa memeroleh skor 7 dengan persentase sebesar $51,43 \%, 11$ siswa memeroleh skor 8 dengan persentase $31,43 \%, 2$ siswa memeroleh skor 9 dengan persentase sebesar $5,71 \%$, dan 2 siswa memeroleh skor 10 .

Skor rata-rata siswa pada tes ini yaitu 7,43 dengan persentase sebesar $62,83 \%$. Skor yang diperoleh dengan menggunakan teknik korelasi Product Moment. Berdasarkan hasil perhitungan diperoleh bahwa $\mathrm{rh}<\mathrm{rt}$ $(0,240<0,334)$. Dengan demikian dapat disimpulkan bahwa tidak terdapat hubungan positif yang signifikan antara penguasaan tata bahasa Jerman dengan keterampilan menulis paragraf deskriptif. Hal ini menunjukkan 
bahwa penguasaan tata bahasa Jerman hanya memberikan kontribusi terhadap keterampilan menulis sebesar $24 \%$.

\section{KESIMPULAN}

Skor rata-rata yang diperoleh siswa pada tes penguasaan tata bahasa Jerman adalah $58,65 \%$, tes keterampilan menulis paragraf deskriptif adalah 62,83\%. Nilai korelasi antara penguasaan tata bahasa Jerman dengan penguasaan tata bahasa Jerman dengan keterampilan menulis sebesar 0,240 ( $\mathrm{r}_{\text {hitung }}=$ $\left.0,240<\mathrm{r}_{\text {tabel }}=0,334\right)$ yang menandakan bahwa tidak ada hubungan positif yang signifikan antara penguasaan tata bahasa Jerman dengan keterampilan menulis paragraf deskriptif.

\section{DAFTAR PUSTAKA}

Arikunto, Suharsimi. 2010. Dasar-dasar Evaluasi Pendidikan. Jakarta: Bumi Aksara

Clamer, F \& Heilman, E.G. 2002.Deutsch als Fremdsprache (Übungsgrammatik für die Grundstufe). GermanyDartmann: Verlag Liebaug.

Dalman. 2015. Keterampilan Menulis, Cetakan Ketiga. Jakarta: Rajawali Pers.

Damayanti, Rini. 2015.Bahasa Indonesia Untuk Perguruan Tinggi. Surabaya.

Destari, Pramita. 2013. Kontribusi Penguasaan Struktur Kalimat dan Kosa Kata Terhadap Kemampuan Menulis Baha Jerman Peserta Didik Kelas XI SMA Negeri 3 Palangkaraya. Skripsi. Universitas Negeri Yogyakarta. Yogyakarta.
Djiwandono, M. Soenardi. 2008. Tes Bahasa Pegangan Bagi Pengajar Bahasa.Jakarta. PT Indeks.

Enre, Fachrudin Ambo. 1988. Dasar-dasar Keterampilan Menulis. Jakarta: Depdikbud.

Fitriani, Lia. 2014. Kontribusi Penguasaan Gramatika Bahasa Jerman Terhadap Keterampilan Membaca Bahasa Jerman Peserta Didik Kelas XI SMA Negeri Sedayu Bantul. Skripsi. Universitas Negeri Yogyakarta. Yogyakarta.

Ghozali, Imam. 2013. Aplikasi Analisis Multivariate dengan Program SPSS 21. Semarang: Badan Penerbit UNDIP.

Komaidi, Didik. 2007. Aku Bisa Menulis. Yogyakarta: Sabda Media.

Mantasiah, R. 2016. Kohesi Dalam Wacana Buku Kontakte Deutsch: Suatu Kajian Analisis Wacana (Cohesion in Discourses of Kontakte Deutsch Book: a Study of Discourse Analysis). SAWERIGADING, 15(3), 336-348.

Mulyati, Sri. 2015. Pengaruh Penguasaan Kosakata, Penguasaan Gramatik dan Kecerdasan Emosional terhadap Keterampilan Menulis Bahasa Jerman Peserta Didik Kelas XI SMA Negeri 1 Imogiri Bantul. Skripsi. Universitas Negeri Yogyakarta. Yogyakarta.

Nurmiati, N., \& Mantasiah, R. 2017. Keefektifan Penggunaan Metode Pembelajaran Tutor Sebaya (PeerTeaching) Dalam Kemampuan Membaca Memahami Bahasa Jerman Siswa Kelas XI IPA SMA Negeri 1 Bontonompo Kabupaten Gowa. Eralingua: Jurnal 
Hubungan antara Penguasaan Tata Bahasa Jerman dengan Keterampilan Menulis Paragraf Deskriptif Siswa Kelas XI SMA Negeri 1 Palopo

Pendidikan Bahasa Asing dan Sastra, 1(1).

Pringgawidagda, Suwarna. 2002. Strategi Penguasaan Berbahasa. Yogyakarta : Adicita Karya Nusa.

Rahman, Niaryanti. 2015. Hubungan Antara Penguasaan Gramatik Dengan Keterampilan Menulis Karangan Sederhana Bahasa Jerman Siswa Kelas XI SMA Negeri 2 Rantepao Kabupaten Toraja Utara. Skripsi pada Jurusan Pendidikan Bahasa Jerman UNM: tidak diterbitkan.

Sugiyono. 2015. Metode Penelitian Pendidikan.Bandung: Alfabeta.

Tarigan, Djago. 2014. Membina Keterampilan Menulis Paragraf dan Pengembangannya. Bandung: Angkasa Bandung.

Tarigan, H.G. 2013.Menulis Sebagai Suatu Keterampilan Berbahasa. Bandung: Angkasa Bandung.

Wiyanto, Asul. 2004. Menulis Paragraf. Jakarta: Gramedia 